\title{
Coupled modeling approach to assess climate change impacts on groundwater recharge and adaptation in arid areas
}

\author{
H. Hashemi ${ }^{1}$, C. B. Uvo ${ }^{2}$, and R. Berndtsson ${ }^{1}$ \\ ${ }^{1}$ Center for Middle Eastern Studies and Department of Water Resources Engineering, Lund University, Box 118, \\ 22100 Lund, Sweden \\ ${ }^{2}$ Department of Water Resources Engineering, Lund University, Box 118, 22100 Lund, Sweden
}

Correspondence to: H. Hashemi (hossein.hashemi@tvrl.lth.se)

Received: 18 September 2014 - Published in Hydrol. Earth Syst. Sci. Discuss.: 24 October 2014

Revised: 27 September 2015 - Accepted: 28 September 2015 - Published: 16 October 2015

\begin{abstract}
The effect of future climate scenarios on surface and groundwater resources was simulated using a modeling approach for an artificial recharge area in arid southern Iran. Future climate data for the periods of 2010-2030 and 2030-2050 were acquired from the Canadian Global Coupled Model (CGCM 3.1) for scenarios A1B, A2, and $\mathrm{B} 1$. These scenarios were adapted to the studied region using the delta-change method. A conceptual rainfall-runoff model (Qbox) was used to simulate runoff in a flash flood prone catchment. The model was calibrated and validated for the period 2002-2011 using daily discharge data. The projected climate variables were used to simulate future runoff. The rainfall-runoff model was then coupled to a calibrated groundwater flow and recharge model (MODFLOW) to simulate future recharge and groundwater hydraulic heads. As a result of the rainfall-runoff modeling, under the B1 scenario the number of floods is projected to slightly increase in the area. This in turn calls for proper management, as this is the only source of fresh water supply in the studied region. The results of the groundwater recharge modeling showed no significant difference between present and future recharge for all scenarios. Owing to that, four abstraction and recharge scenarios were assumed to simulate the groundwater level and recharge amount in the studied aquifer. The results showed that the abstraction scenarios have the most substantial effect on the groundwater level and the continuation of current pumping rate would lead to a groundwater decline by $18 \mathrm{~m}$ up to 2050 .
\end{abstract}

\section{Introduction}

Groundwater (GW) is the major source of fresh water for humans. However, during the last decades, GW decline has been observed both at local and regional scale. GW reserves constitute more than $70 \%$ of water supply in arid environments (Rosegrant and Ringler, 2000; Llamas and MartínezSantos, 2005; Siebert et al., 2010; Surinaidu et al., 2013) now often being depleted due to over-extraction for irrigated agriculture. Also, due to climate change, it is anticipated that GW will be increasingly important in arid areas due to extended drought periods (IPCC-TGICA, 2007) that most likely will lead to less surface water availability. Further, as many GW reservoirs are non-renewable on meaningful timescales for human society (Kløve et al., 2014), climate change adaptation through aquifer management is an urgent need to balance and, especially, rehabilitate already depleted aquifers.

$\mathrm{GW}$ recharge and abstraction are the major constraints for safe GW yield (Döll and Flörke, 2005). In most arid and semi-arid environments, direct recharge from rainfall is considered to be less than $1.0 \%$ of the total rainfall. Thus, GW recharge mainly takes place during the runoff process (Dugan and Peckenpaugh, 1985; Bedinger, 1987; Bouwer, 1989, 2000). Runoff generation highly depends on rainfall quantity and intensity, morphological and geological characteristics, and land-surface coverage of the catchment. In most cases, runoff will eventually end up in terminal salt lakes, swamps, or the sea. There are techniques that can be employed to artificially recharge the $\mathrm{GW}$ by diverting runoff from a river channel to the designated recharge area, e.g., spreading basin, infiltration pond, or injection well. 
For instance, floodwater spreading for artificial recharge is a technique by which destructive flash flood is diverted onto the spreading basins. High velocity flash floodwater enters the consecutive basins, slows down, and spreads uniformly on the flat area where it infiltrates and augments the GW. Yet, natural and artificial recharge systems in arid environments are, inherently, dependent on floodwater/runoff availability. It is important to keep in mind that climate change may influence runoff quantity and its temporal variability and result in more uncertainty in the future GW recharge. Therefore, studies on climate change impacts on both surface water and GW is necessary.

A comprehensive climate change review by Dore (2005) reveals increased variation of precipitation all over the world with elevated precipitation in wet and reduced precipitation in dry regions. While there is uncertainty in climate change projections regarding whether there will be an increase or decrease in temperature and precipitation in most parts of the world (e.g., McMichael et al., 2004; Bell et al., 2004; Zhang et al., 2006; Priyantha Ranjan et al., 2006; Jyrkama and Sykes, 2007; Beniston et al., 2007; Giorgi and Lionello, 2008; Toews and Allen, 2009; Barthel et al., 2012), the majority of climate models predict a noticeable decrease in precipitation and an increase in temperature in the arid Middle East (e.g., Bou-Zeid and El-Fadel, 2002; Felis et al., 2004; Abbaspour et al., 2009; Evans, 2009, 2010).

Climate change impacts are expected to be more extreme in the arid world including the Middle East. On the other hand, the regions' countries are mostly considered as developing where building large hydraulic infrastructure might not be consistent with their economic situations. Hence, adaptation is needed to cope with changing water resources. The impacts on GW resources may be even more severe due to decreased precipitation and increased potential evapotranspiration (ETP) that may result in more intense GW abstraction in the future (Brouyère et al., 2004; Surinaidu et al., 2013). Therefore, an adaptive approach that takes into account the past, current, and future conditions of the hydrological cycle is necessary to manage this vital resource in a sustainable way. Moreover, an appropriate technique needs to be applied in order to appropriately predict the future $\mathrm{GW}$ availability in particular regions.

Many techniques have been applied for climate change impacts on GW recharge and their influence on reservoirs. These techniques include direct effects of projected precipitation (e.g., Candela et al., 2009) or runoff (e.g., Eckhardt and Ulbrich, 2003) on recharge and groundwater level (GWL). A common approach for subsurface hydrology prediction is to use the results acquired from general circulation models (GCMs). This involves downscaling of the projections from a course grid scale of a GCM to a finer scale, creating time series of future possible recharge periods, and applying the projected recharge periods as an input to the hydrological models (Barron et al., 2010, 2012).
For climate change impact studies on GW systems, an integrated multidisciplinary monitoring approach is necessary to better define the interaction between all hydrologic components and land use management. Though, the acquisition of atmospheric, surface water and GW data, as well as with land use changes and water extraction, are fundamental. Then, modeling is needed to link these complex processes (Kløve et al., 2014).

\section{Review of different modeling approaches in assessing climate change impacts on groundwater resources}

The main aim of studying climate change impacts on $\mathrm{GW}$ systems is to predict the (1) changes in GW recharge rate in different recharge periods (e.g., Eckhardt and Ulbrich, 2003; Scibek and Allen, 2006; Jyrkama and Sykes, 2007; Toews and Allen, 2009; Meddi and Boucefiane, 2013) and to predict the (2) change in GW levels (e.g., Surinaidu et al., 2013; Goderniaux et al., 2009). These objectives are commonly achieved through numerical modeling approaches.

The choice of modeling approach to assess the climate impacts on GW is dependent on the system complexity and modeler preferences. For assessing climate change impact on recharge, the easiest way may be to use a simple regression model, which is used to predict the recharge rate where annual recharge is assumed to vary linearly with annual rainfall (Barron et al., 2010). For this, GCM simulated precipitation rates are used to predict inflow to a calibrated GW model (e.g., Hanson and Dettinger, 2005; Surinaidu et al., 2013). In a similar way, Surinaidu et al. (2013) employed a GW modeling approach to estimate the aquifer parameters and $\mathrm{GW}$ flow in a large river basin in humid southwestern India. In their study, the net recharge from all hydrological components and GW discharge in the studied catchment was estimated based on empirical equations derived between rainfall data and GWL. Accordingly, the average GW recharge coefficient was estimated to be $11 \%$ of annual rainfall. They also applied linear regression between historical rainfall and river discharge data to estimate the potential surface water available in the future, which then was added to the annual estimated recharge for the future climate scenarios.

According to this method, the predicted recharge is mainly based on direct precipitation, which may not be accurate, particularly, in arid regions where the direct rainfall recharge is expected to be less than $1.0 \%$ of the corresponding rainfall amount (Dugan and Peckenpaugh, 1985; Bedinger, 1987). In addition, GW recharge has a random behavior depending on the sporadic, irregular, and complex features of storm rainfall occurrence, land cover and land use variability, soil moisture, and geological composition (Şen, 2008). This leads to nonlinear relationships between precipitation and recharge. Further, $\mathrm{Ng}$ et al. (2010) defined that for most climate change estimates, predicted changes in average recharge are larger than the corresponding changes in average precipitation pri- 
marily due to temporal distribution of precipitation change (over seasons and rain events) and a complex mix of climate and land-surface factors. Another major limitation of this approach is the lack of subsurface conceptualization of the system (Surinaidu et al., 2013). However, this method can be assumed to be a viable approach for the subsurface scarcedata region of the world.

Some researchers have used the linear storage method (Robock et al., 1995; Barron et al., 2010) to predict recharge based on a series of descending storages to estimate the water storage in soil layers. It is assumed that the direct areal recharge to the aquifer occurs from a combination of weather data, stream, soil characteristics, vegetation, and land cover data. Some widespread models using this method are HELP and SWAT (e.g., Eckhardt and Ulbrich, 2003; Jyrkama and Sykes, 2007; Toews and Allen, 2009; Abbaspour et al., 2009). The linear storage models, also known as bucket models, define the role of soil moisture for ETP by distinguishing radiation-limited regimes and soil moisture-limited regimes (Seneviratne et al., 2010); i.e., in which a near-surface layer of soil is modeled as a storage that can be filled by infiltrating precipitation and exposed to evaporation and runoff if filled up (Henderson-Sellers et al., 1993). The storage models represent an important attempt to capture soil moisture limitation on ETP in climate models. Nevertheless, studies have revealed that the model parameterizations are inadequate as plants' transpiration as well as soil moisture is not included in the calculation leading to overestimation of ETP (e.g., Henderson-Sellers et al., 1993; Robock et al., 1995). In addition, the bucket models do not consider interception storage and geographical variations in soil and vegetation parameters that may result in over-/underestimation of runoff quantity (Seneviratne et al., 2010).

There are also integrated physically based hydrological models that consider water exchange between surface water, unsaturated, and saturated zones within the model frame, e.g., MIKE-SHE, MOHISE, HydroGeoSphere, CATHY, and ParFlow (e.g., Brouyère et al., 2004; Goderniaux et al., 2009, 2011; Ferguson and Maxwell, 2010; Stoll et al., 2011; Sulis et al., 2011). Van Roosmalen et al. (2009) used an integrated process-based surface-groundwater model to study the intricate, nonlinear relationships between the land surface, unsaturated, and saturated zones under changing conditions through the large number of parameters by MIKESHE. Their study showed that climate change has the most substantial effect (compared to irrigation, transpiration, and land use changes) on the hydrology of a large-scale agricultural catchment in Denmark. Nevertheless, the integration of surface and subsurface flow in the same model presents a better conceptualization and accuracy in simulation of water interaction between surface water and GW. Yet, it should be mentioned that, proper calibration of integrated physically based hydrological models depends highly on the quantity of collected data, which may result in less accuracy in data-poor regions. Hence, this method may not be applicable in many arid developing countries, as the monitoring system is often not sufficiently developed to properly characterize the system, e.g., the Middle East.

Kløve et al. (2014) stated that the quantification of climate change impact on GW reservoirs and recharge rates can be explored by GW models with future climate scenarios acquired from GCMs (e.g., Hanson and Dettinger, 2005; Dams et al., 2011; Leterme et al., 2012). Okkonen and Kløve (2011) carried out a sequential simulation of three models to estimate the temporal and spatial variation in surface-groundwater interaction. For this, they used the Watershed Simulation and Forecasting System (WSFS) model to estimate areal precipitation and temperature and to simulate the surface water levels in lakes and rivers in a cold climate watershed in Finland. The output of the WSFS model, precipitation and temperature, was used as input to the CoupModel to simulate aquifer GW recharge rates. The simulated surface water flow and recharge rate were finally imported to MODFLOW to simulate the GW flow, surface-groundwater interaction, and to predict the GWL change in view of future climate change scenarios. Although, they used CoupModel to estimate recharge rate, the estimated value is based on precipitation and temperature and not surface water availability. Barron et al. (2012) employed extensive coupled modeling to project the future GW recharge and GWL at regional scale in Australia. In their study the coupled surface-groundwater model was first calibrated for the period 1975-2007 and the climate sequences were then used as input to the calibrated surface water and process-based GW models for the projection of impacts on runoff and GW balance. They concluded that the methods used are suitable for regional-scale estimates but to assess local impacts on water dependent ecosystems and water yields, finer scale modeling and analysis would be required. According to this approach, coupled modeling between surface and GW is an appropriate method taking into account the generated runoff produced by climate scenarios. This approach can be assumed to be the most appropriate for predicting recharge in arid areas where surface runoff is the major water supplier. However, the appropriate choice of GW model to adequately estimate the recharge rate is fundamental due to insufficiently observed subsurface data in most parts of the arid world.

There are few studies on climate change impacts on GW resources in which the effects of projected rainfall on surface runoff and its consequences on GW recharge are considered, particularly for arid areas and at a local-scale $\left(>100 \mathrm{~km}^{2}\right)$. In view of this, we used a coupled modeling approach for studying climate change impacts on GW resources and adaptation scenarios in an arid region of Iran. We applied sequential modeling that is able to estimate GWL fluctuation, based on already calibrated rainfall-runoff and processedbased GW models. For this, three GCMs scenarios, A1B, A2, and $\mathrm{B} 1$, were used as input to a coupled one-way surfacegroundwater model as it was assumed there is no interaction between surface water and GW resources due to deep GW 
levels, for the periods 2010-2030 and 2030-2050. In the final step, we applied several artificial recharge and pumping scenarios employing the calibrated GW model for recharge rate in order to identify the possible GW management alternatives. In the adaptation scenarios through processed-based GW modeling, variable pumping for irrigated farmlands and management scenarios through floodwater harvesting systems were assumed.

\section{Description of the study site}

The study was carried out in the Gareh Bygone Plain (GBP), which is located between $53^{\circ} 53^{\prime}$ and $53^{\circ} 57^{\prime}$ longitude and $28^{\circ} 35^{\prime}$ and $28^{\circ} 41^{\prime}$ latitude at an altitude ranging from 1125 to $1185 \mathrm{~m}$ a.m.s.l. (above mean sea level), $190 \mathrm{~km}$ southeast of Shiraz City, Iran (Fig. 1). The landscape is low sloping and the plain is composed of a coarse calcareous alluvial fan with an average thickness of 25 to $30 \mathrm{~m}$ on a red-clay bedrock. The plain is mainly covered by sand deposit. This unconsolidated geologic medium has created an unconfined aquifer with an area of 6000 ha constituting part of the 18000 ha plain (Fig. 2).

The climate of the GBP is extremely dry and hot with a minimum and maximum annual rainfall of 55 and $557 \mathrm{~mm}$, respectively. Mean annual rainfall is $255 \mathrm{~mm}$ and the mean annual class-A pan potential evaporation is $2860 \mathrm{~mm}$. Furthermore, temporal and spatial rainfall variation is extreme. The rainfall pattern is mainly influenced by the Mediterranean synoptic system moving from the west to the east of the country. Typically, rain falls after long dry periods as sudden storms and intense showers resulting in flash floods.

There are two ephemeral rivers in the studied area, namely, the Bisheh Zard and Tchah Qootch rivers that discharge from two upper intermountain basins (Bisheh Zard and Tchah Qootch) with catchment sizes of 192 and $171 \mathrm{~km}^{2}$, respectively (Fig. 1). These two ephemeral rivers, with recorded discharge on 107 occasions between 1983 and 2012, comprise the main source of incoming surface water onto the GBP. These rivers join in the lower southeastern part of the GBP. Flood duration typically varies between 2 and $40 \mathrm{~h}$. Due to the physiographical characteristics of the upper basins, a $5 \mathrm{~mm} \mathrm{~h}^{-1}$ intensity rainfall event can generate a significant flash flood. The non-vegetated, steep slope, and the imperviousness of the upper basin surface covered by sandstone, siltstone, and marl are the main factors in determining runoff amount beside the rainfall amount and intensity.

Due to the scant water resources in the GBP, an adaptive approach for artificial recharge of GW through floodwater harvesting was proposed in 1983 to improve the livelihood of the inhabitants. The main purpose was to increase GW availability to support irrigated agriculture. Five different but interconnected floodwater spreading (FWS) systems were first established in 1983 with an area of about 1365 ha and extended to twelve FWS systems with the total area of

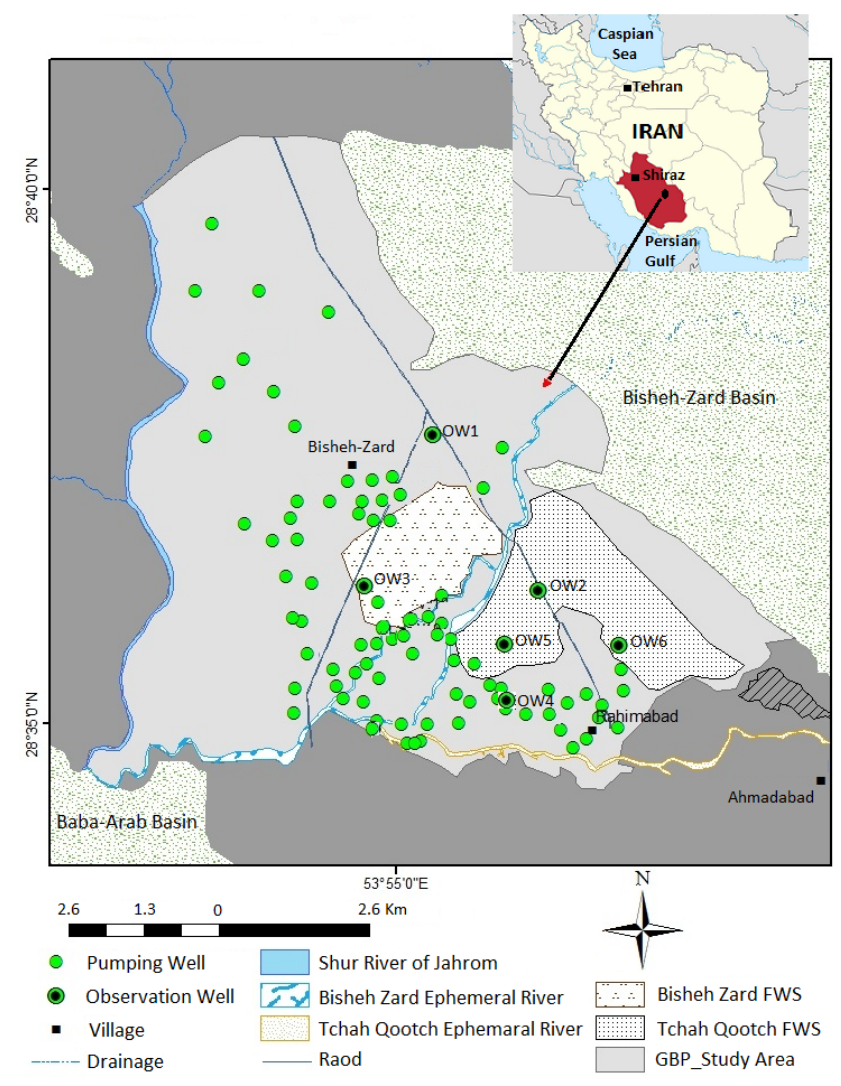

Figure 1. Location of the floodwater spreading systems, observation wells, pumping wells, and river networks within the studied area.

2033 ha in 1996 (Kowsar, 1991, 2008). The system diverts surface runoff from the ephemeral rivers onto the consecutive recharge basins in which the floodwater infiltrates down and percolates to $\mathrm{GW}$ reservoir.

Hashemi et al. (2015) simulated the GW flow and estimated the aquifer GW recharge rate for the GBP by a numerical model. They calculated that the recharge amount in the studied FWS system varied from a few hundred thousand cubic meters per month during drought periods to about 4.5 million $\mathrm{m}^{3}$ per month during rainy periods. Due to the positive effects of the FWS project on GW availability, the area of irrigated farmland has increased eightfold to 1193 ha and the number of pumping wells increased tenfold to 120 wells as compared to the situation in 1983 (Kowsar, 2008). Consequently, the gain through artificial recharge has decreased through too much abstraction by the numerous new-drilled pumping wells after 1996. Hence, the GW declined over $10 \mathrm{~m}$ in spite of the artificial recharge system.

\section{Materials and methods}

The analyses of climate change effects on surface water and GW resources were based on (1) delta-change approach, 


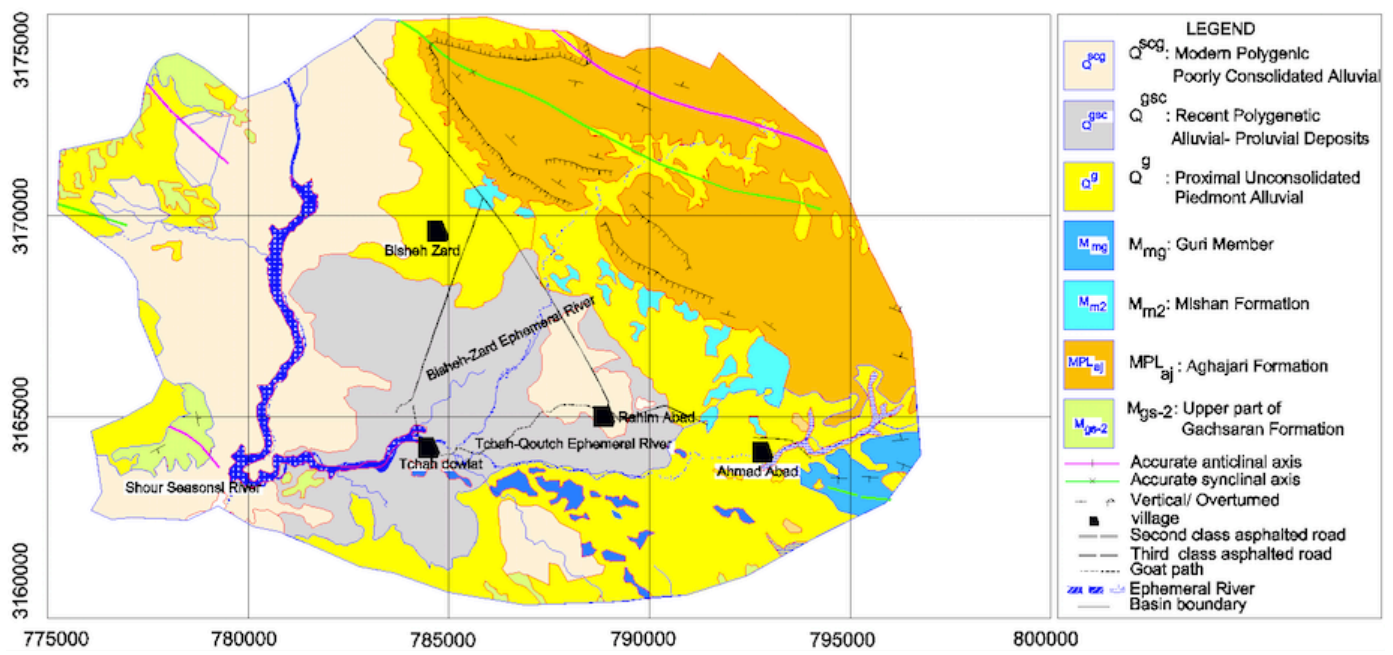

Figure 2. Geological map of the Gareh Bygone Plain and the upper basin (Bisheh Zard).

(2) hydrological modeling, and (3) GW modeling. Accordingly, the application of different modeling and climate change projections used (1) climate scenarios; (2) atmospheric data, i.e., rainfall, temperature, and ETP; and (3) hydrological data, i.e., flood records and GW hydraulic heads.

\subsection{Climate scenarios}

Global climate models also known as GCMs are used to assess climate, variability, and vulnerability in the future based on historical records. In this study, we used outputs of the Canadian Global Coupled Model (CGCM 3.1) (Flato et al., 2000) version T63, which has a surface grid with a spatial resolution of $2.81^{\circ}$ latitude by $2.81^{\circ}$ longitude and $31 \mathrm{lev-}$ els in the vertical (Abbaspour et al., 2009). With this resolution, 36 grid points fall inside the entire Iranian territory. Accordingly, three commonly used daily based climate change scenarios, A1B, A2, and B1, were taken into account considering the climate conditions for the near (2010-2030) and far (2030-2050) future. CGCM baseline data between 1961 and 2000 were used for impact assessments. The baseline data were used to define the changes in climate between the present-day and future conditions (IPCC-TGICA, 2007) through delta-change approach.

Based on the IPCC-TGICA (2007) report, the A1B scenario depicts a world with a balanced use of fossil and nonfossil fuel as a main energy source. It assumes very rapid economic growth and population reaches 8.7 billion in 2050 . The A2 scenario describes a very heterogeneous world. The underlying theme is self-reliance and preservation of local identities. Economic development is primarily regionally oriented and per capita economic growth and technological changes are more fragmented and slower than in other scenarios. The B1 scenario describes a convergent world with the same global population that peaks in mid-century and declines thereafter (lower than A2), but with rapid changes in economic structures toward a service and information economy. The emphasis is on global solutions to economic, social, and environmental sustainability, including improved equity, but without additional climate initiatives.

\subsection{Atmospheric data}

The longest recorded climate data in the area (since 1972) belong to the Baba Arab meteorological station, $15.7 \mathrm{~km}$ southwest of the GBP. Thus, the data collected in this station were used for climate change projections. The average annual rainfall difference between GBP and Baba Arab is less than $5 \mathrm{~mm}$ taking into account the available data in both stations.

Daily rainfall, temperature, and ETP data from the Baba Arab station were used for the hydrological projections. Since the studied area is relatively small $\left(60 \mathrm{~km}^{2}\right)$, it was assumed that the climate variables are constant over the entire area for the studied period by using one meteorological station. As the future projection is based upon 20-year time intervals, all climate scenarios were assigned based upon the most recent observed daily time sequences of climate variables from 1 January 1990 through 31 December 2009.

\subsection{Hydrological data}

Due to missing observed daily potential evaporation for the years between 1990 and 2001, a statistical method was used to project ETP using daily temperature records. For this, the available observed daily ETP as a function of temperature was calculated between 1 October 2002 and 30 September 2011 (Fig. 3). The result shows a strong correlation between ETP and temperature for the studied area $\left(R^{2}=0.82\right)$. In all future scenarios, the derived regression equation was applied to the projected temperature to achieve anticipated potential evaporation for the same periods. 


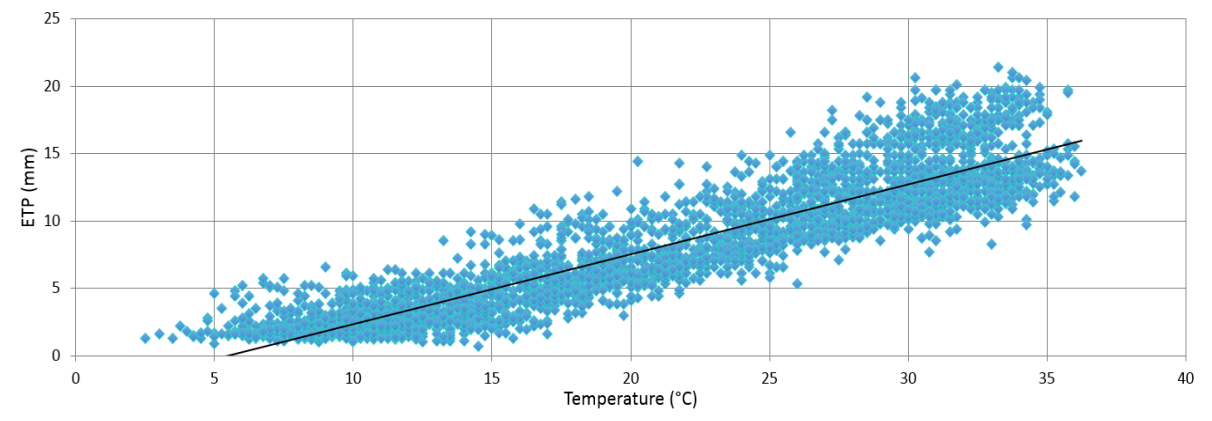

Figure 3. Observed daily mean temperature vs. observed daily potential evapotranspiration (ETP) at the Baba Arab meteorological station for the period from 1 October 2002 through 30 September 2011.

As mentioned before, there are two ephemeral rivers flowing down from the upper intermountain catchments in the studied area, which are the main sources of flash floodwater into the FWS systems. However, there is no reliable observed discharge data for these rivers, and yet the GW recharge model only works with flood periods and not the magnitude of the floods. Thus, we decided to use the recorded discharge data at the outlet of the contiguous basin, Baba Arab Basin, with similar characteristics to the studied areas' upper catchments in terms of geology, topography, land use, and climatology (Figs. 1 and 2). Accordingly, the recorded daily data of Baba Arab discharge station were applied in a rainfall-runoff model to simulate the stream flow from 1 October 2002 through 30 September 2011.

In the studied aquifer, GW hydraulic heads have been recorded on a monthly basis since 1993 by the Fasa District Water Organization. The observed data from six boreholes distributed within the GBP were used in this study to simulate GW flow and estimate aquifer hydraulic parameters between 1993 and 2007. To verify the GW modeling results, the measured hydraulic parameter values derived from two pumping tests (Hashemi, 2009) were also taken into account to compare with the estimated values.

\subsection{Delta change}

Okkonen and Kløve (2011) stated that the delta-change approach (Hay et al., 2000) has the advantage of preserving observed patterns of temporal and spatial variability from the observations of precipitation and temperature. It is also more relevant to directly compare the observations and future scenarios. Accordingly, the delta-change approach was used to define the differences between the CGCM-simulated current (baseline, 1961-2000) and future scenarios (A1B, A2, and B1 and for periods 2010-2030 and 2030-2050). The derived differences were applied to the historical/observed data to generate future scenarios. It is noted that all future CGCMs output data (from 2010 through 2050) were divided into two 20-year periods, 2010-2030 and 2030-2050. Accordingly, the most recent 20-year historical data, between 1990 and
2010, were used to generate climate data for hydrological projections by repeating the 20 -year observed data in both periods of climate scenario.

In the first step, as the local conditions may vary from what we observe from a large scale and in order to regionalize the CGCMs outputs of the entire country, average daily values for all 36 grids covering the whole country were calculated. The calculations were done for both baseline and future scenarios in order to achieve only one value for each single day out of 36 grids. Then, the differences between the average daily values of the baseline and all future scenarios were derived. In the final step, the derived difference of rainfall and evaporation between the baseline and future scenarios (in percent) was multiplied with the daily values of historical data between 1 January 1990 and 30 December 2009. In the case of temperature data, the observed values (historical data) were scaled by adding the calculated differences between baseline and future scenarios.

\subsection{Description of the numerical models}

The analysis of climate change impacts on the GW reservoir in the studied region was based upon the projected runoff and subsequent recharge as results from the rainfallrunoff (Qbox) and GW (MODFLOW, Harbaugh et al., 2000) modeling. Since the GWL in arid and semi-arid areas, including GBP, is rather deep and the variation in adjacent surface water level is not affected by GW discharge, there is no need for two-way coupling and, thus, one-way coupling between surface runoff and GW reservoir would suffice (Ataie-Ashtiani et al., 1999). Accordingly, a sequential surface-groundwater modeling was undertaken to project the GWL and GW recharge for the future studied periods. In the first step, the projected climate variables for scenarios A1B, $\mathrm{A} 2$, and $\mathrm{B} 1$ were used as input to the calibrated rainfallrunoff model to project future runoff. In the next step, the projected runoff was used in the calibrated GW model to simulate GW recharge in both near and far future. In the final step, four different adaptation and management scenarios for GW artificial recharge and abstraction rates were applied to 


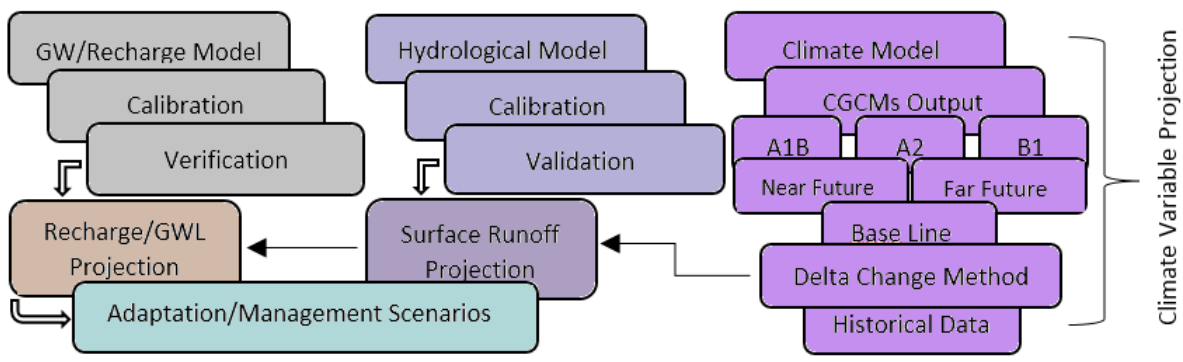

Figure 4. Flow chart showing the methodology used in this study to project climate change impacts on surface water and groundwater recharge/level.

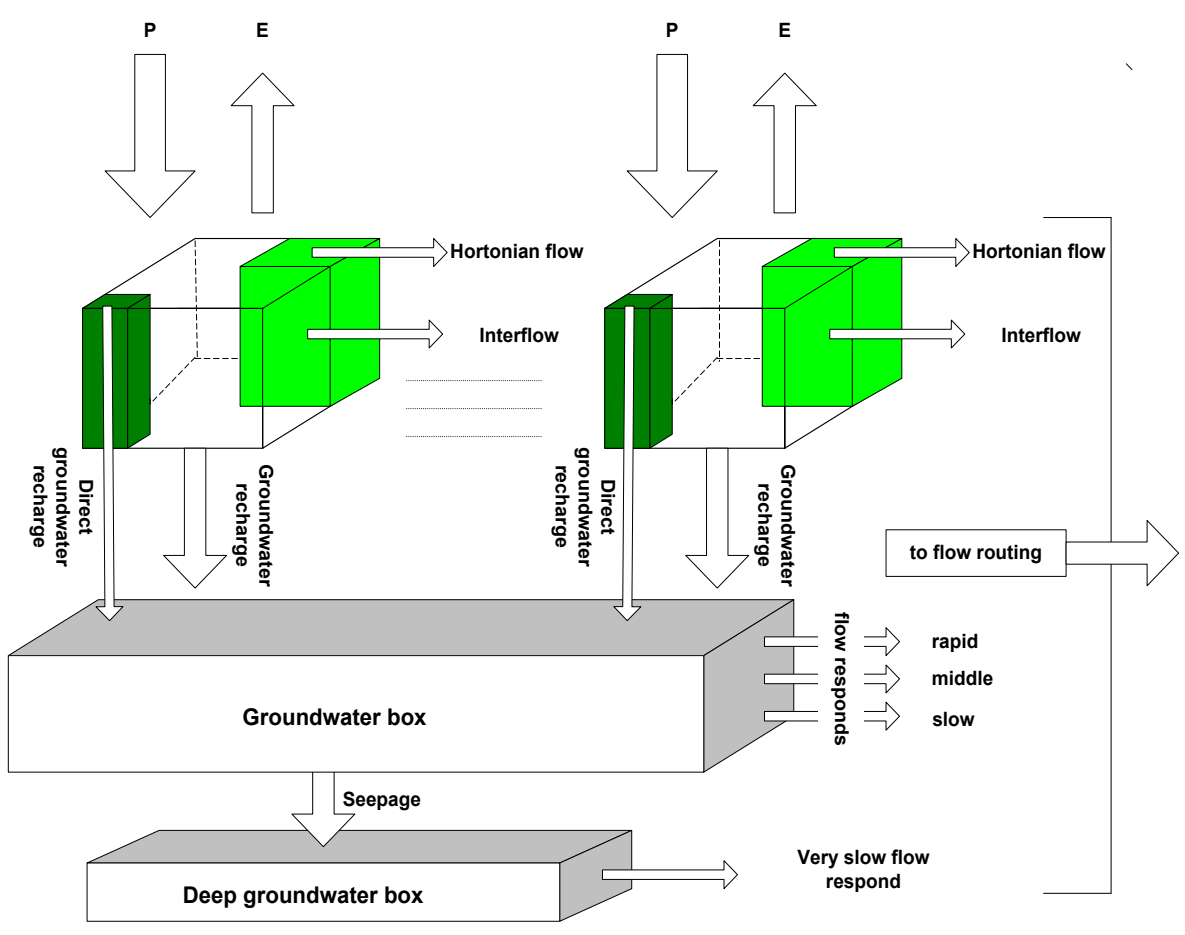

Figure 5. Structure of the Qbox rainfall-runoff model (source: Iritz, 2014).

the process-based GW model in order to assess the GW safe yield for the next 40 years (Fig. 4).

\subsubsection{Hydrological modeling}

Rainfall-runoff modeling can be used to simulate runoff from a basin for given meteorological data. Future runoff was simulated using a conceptual box model (Qbox) utilizing the three future climate scenarios. The model is a modified version of the Hydrologiska Byråns Vattenbalansavdelning (HBV) model (Lindström et al., 1997) in terms of structure, parameterization, and performance. Qbox (Iritz, 2014) is a general tool for hydrological modeling of water movement through a river basin. In principal, the model is constituted by different linear storages placed vertically above each other (Fig. 5). The model is built on the continuity equation (Eqs. 1 to 4) for each box and a number of auxiliary rela- tionships. In the model, soil water located between the soil surface and the GW table is treated as if it was in a storage (or reservoir). The percolating water from each storage is recharging the upper storage or reservoir. The level in the storage rises due to infiltrating precipitation and sinks due to evaporation. In other words, water leaves the upper storage as evaporation, which is directly coupled to the atmosphere, as deep percolation, and as runoff (outflow) to a river system. Not until the storage is full, which corresponds to water content reaching field capacity, the water from the storage contributes to runoff. Water surplus percolates to deep GW. Accordingly, the continuity equation for a soil box is:

$\frac{\mathrm{d} h_{\text {soil }}}{\mathrm{d} t}=p-e-f ; e, f=$ fun $\left(h_{\text {soil }}\right)$,

where $h_{\text {soil }}$ is the amount of water in soil-water storage, $p$ is precipitation, $e$ is evaporation, and $f$ is $\mathrm{GW}$ generation or 
percolation, which is modeled as rate of filling of simple or double reservoir. The rate of recharge, $f$, is limited to $f_{\max }$, i.e., $f$ is $\max \left(f_{x}, f_{\max }\right)$. This means that although much rainwater enters the soil, the soil water does not contribute to GW recharge at a faster rate than $f_{\max }$. The recharge formula is

$$
f_{x}=p\left(\frac{h_{\mathrm{s}}}{h_{\mathrm{fc}}}\right) \text { when } h_{\mathrm{s}}>h_{\text {stop }},
$$

where $h_{\mathrm{fc}}$ represents field capacity, i.e., a representative soilwater storage when the entire zone is at field capacity. A parameter $h_{\text {stop }}$, has the function of completely stopping $\mathrm{GW}$ recharge when the soil-water storage drops below $h_{\text {stop }}$.

The rate of evaporation depends on ETP and as a function of soil-water content, $e=\operatorname{ETP} f\left(h_{\text {soil }}\right)$ :

$e=p e\left(\frac{h_{\mathrm{s}}}{h_{\mathrm{e}}}\right)^{\propto}$ but $e=p e$ when $h_{\mathrm{s}}>h_{\mathrm{e}}$

where $\alpha$ is an exponent, less than 1 , and $h_{\mathrm{e}}$ is the soil moisture above which the evaporation takes place at the potential rate. The rate of percolation depends on rain intensity and soil-water content, $f=f\left(p, h_{\text {soil }}\right)$. The part of the rainfall, which has a higher intensity than the maximum infiltration capacity of the soil, i.e., after some time the difference between the rain intensity and the hydraulic conductivity at saturation, contributes to Hortonian surface runoff. Hence, outflow at the bottom of the soil-water box forms inflow to the runoff box. This runoff contribution must first fill up depression storage before real surface runoff occurs. Calculation of surface runoff can be made using a nonlinear reservoir or a reservoir with a small time constant. An addition to the rainfall-runoff model is to use a deep GW box. Though, water percolates from the runoff storage into the deep GW storage. The continuity equation for the runoff storage and the deep GW storage is

$$
\frac{\mathrm{d} h}{\mathrm{~d} t}=f-q-i_{\mathrm{p}} ; q=\sum q=\text { fun }\left(h_{\mathrm{soil}}\right),
$$

where $q$ is surface runoff and $i_{\mathrm{p}}$ is deep percolation.

In this study, the rainfall-runoff model was first calibrated using daily data from Baba Arab discharge station for the historical climate period between 1 October 2002 and 30 September 2008 . Then, the model was validated for daily data between 1 October 2008 and 30 September 2011. The calibrated model was used to simulate future runoff by utilizing future climate variables projected by the delta-change method. The future-simulated runoff was finally imported to the GW model to simulate the GW flow, estimate the GWL, and recharged water volume.

\subsubsection{Groundwater modeling}

For the future recharge projections, the output of the rainfallrunoff model (future projections) was assigned as the input to the GW model. The projected flood events (inundation of ephemeral river channels and FWS basins) were considered as recharge periods in the GW model. For this, the recharge package in MODFLOW was used to simulate the recharge flux distributed over the area, i.e., recharge basins and river channels, and specified in units of length/time, i.e., flood period or flooding time. It is noted that the magnitude of a flood, i.e., flood discharge rate per time unit, cannot be specified in the recharge package; however, it can be incorporated into simulation by extending or diminishing the recharge areas. Further, the mean estimated recharge rate is acquired from the 14-year calibrated model and assigned as a recharge rate for all future scenarios. It is noted that not all the surface runoff is diverted to the artificial recharge systems but only when the runoff reaches a certain level. Though, according to the hydraulic structure of the diversion dam and conveyor canal in the FWS systems, it was assumed that when the flood peaks are exceeding $15 \mathrm{~m}^{3} \mathrm{~s}^{-1}$, the flood is diverted to the system and recharge takes place through both the river channel and the FWS systems. Although the recharge occurs through the river channel in either case (more than $15 \mathrm{~m}^{3} \mathrm{~s}^{-1}$ and less than $15 \mathrm{~m}^{3} \mathrm{~s}^{-1}$ ), for small flood events the river channel contributes only $20 \%$ or less in total recharge. Hence, no recharge was assumed in the GW model in this case.

\subsection{Adaptation scenarios through groundwater modeling}

Artificial recharge through FWS has been actively promoted in different parts of arid Iran since the 1980s (Ghayoumian et al., 2005). The main objective of the system is GW augmentation and spate irrigation to increase agricultural productivity and, in general, enhancing rural livelihood conditions. Although, artificial GW recharge has been one of the main interest of the governmental policy throughout the last couple of decades, illegal pumping and over-exploitation of aquifers have been the main challenge decreasing this vital resource. As the abstraction rate often exceeds the natural recharge of $\mathrm{GW}$, four different GW recharge and abstraction scenarios were applied to the calibrated GW model taking into account all climate scenarios (A1B, A2, and B1) during the near and far future periods.

In the first scenario, the average abstraction rate between 1993 and 2007 (considering all existing active 80 wells in 2007) was assigned to the model. A maximum recharge contribution through both artificial recharge systems and the natural river channel was considered in the model taking into account the output of the rainfall-runoff model. In the second scenario, pumping was assumed the same as in scenario one; however, the artificial recharge area was decreased by half in order to consider the influence of the FWS on the GW reservoir considering the size of the system. In the last two scenarios, the abstraction regime was assessed. In these scenarios, two negative abstraction growth rates were mod- 

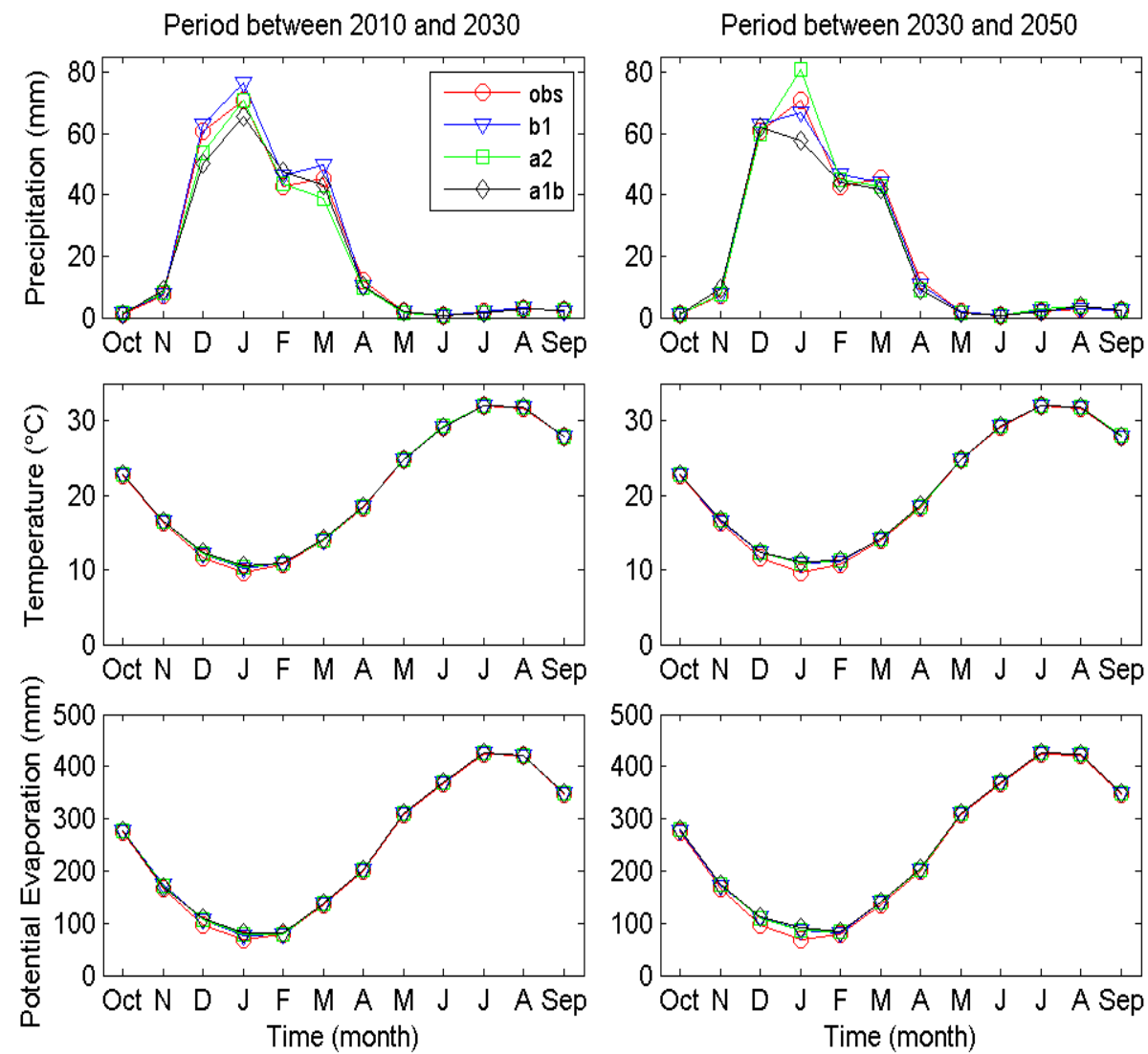

Figure 6. Mean monthly precipitation $(\mathrm{mm})$, temperature $\left({ }^{\circ} \mathrm{C}\right)$, and potential evaporation $(\mathrm{mm})$ for historical climate data (1990-2010) relative to A1b, A2, and B1 scenarios for the periods 2010-2030 and 2030-2050.

eled based on control rate, which was used in the first and second scenarios (average rate between 1993 and 2007). Accordingly, in the third scenario, a maximum recharge was assumed including all existing recharge sources but the number of pumping wells was decreased by half (half of pumping wells were randomly turned off). In the fourth scenario, a maximum recharge was assumed considering all recharge areas and future flood periods, with no abstraction by pumping wells (all pumping wells were turned off in the model).

\section{Results}

In the following sections the hydrological effects and adaptation scenarios of climate change in an arid region are presented. The projections were carried out for both the near and far future. It is noted that daily time steps were used in the climate variable and runoff projections, but a monthly time step was used in the GW recharge projection. This is because the GW model was calibrated based on available monthly recorded data. Thus, the monthly average value of projected runoff was assigned as input to the GW model.

\subsection{Effect of climate change on climatological regime}

Figure 6 presents the projected precipitation, temperature, potential evaporation for all scenarios, and corresponding variables of historical data. As shown, in the future scenarios, there are no significant changes in the climate variables during the spring and summer seasons (from April through October) relative to the historical climate. It can be concluded that based upon CGCMs outputs and the delta-change method, the climate of the studied region will be almost the same as during the last 20 years (1990-2010) for the summer season. Hashemi et al. (2015) showed that since the beginning of 1990s the drought period has been the dominant climate condition for the studied area (Fig. 7). This has caused severe GW decline mainly due to the severe drought as well as over-tapping of GW resulting in less rainfall and high evaporation during the warm season. It is noted that by using the delta-change approach and considering no significant changes in the future climate, the time series of future climate variables more or less replicate the historical climate pattern (Fig. 6). Since the future time series of climate variables were generated based upon the last 20 years of available climate data, it is seen that frequent drought periods with the same rate of the historical period (1990-2010) will continue 


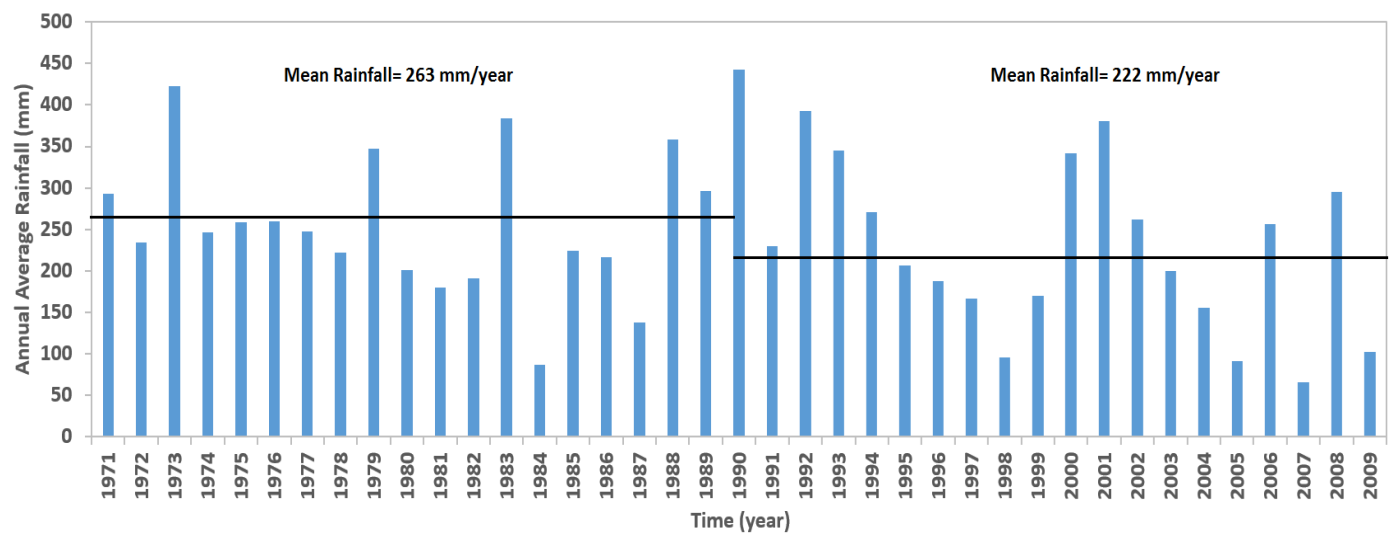

Figure 7. Comparison of mean annual rainfall for the periods 1971-1990 and 1990-2010.

up to 2050 . Consequently, the water resource will be further stressed in the coming decades.

During the cold and wet season (November through March), temperature and potential evaporation are slightly increased in all projected scenarios. The increase reaches a maximum of $1.5^{\circ} \mathrm{C}$ in January under the A1B scenario for the near future. An increase in temperature in the cold and wet season caused an increase in potential evaporation up to $24 \mathrm{~mm}$ for January. The average increases (based on A1B scenario) in temperature for the near and far future were 1.0 and $1.6 \%$, respectively. The impacts of climate change on temperature and potential evaporation under scenarios A2 and $\mathrm{B} 1$ are almost the same for both future periods with minimum difference in comparison with historical records. Under scenario A1B, an increase in both potential evaporation and temperature may cause a decrease in future water availability.

Figure 6 shows a slight change in precipitation for summer months between May and November and the different scenarios. In these months, the projected precipitation (in all scenarios) replicates to some extent historical records. For the wet and cold months (November through May), a gradual reduction in precipitation between November and February can be seen under the A1B scenario for both future periods. This reduction reached a maximum in January for the far future scenario. In general, the average reduction in precipitation in the near and far future is about 2.0 and less than $1.0 \%$, respectively. In the near future, under the B1 scenario an increase in precipitation for the entire wet and cold months is projected, while an increase in precipitation is dominant for the far future under scenario A2.

\subsection{Rainfall-runoff modeling and runoff projection}

\subsubsection{Model calibration and validation}

The calibration and validation of the rainfall-runoff model were performed using observed daily discharge data from the Baba Arab discharge station. The parameterization of the model was partially based on the physiographical charac- teristics of the basin acquired from topographical maps and satellite imageries. Figure 8 shows a comparison between observed and simulated discharge for the entire model period. The model was first calibrated using observed daily data for the period 1 October 2002 through 30 September 2008. Then, the optimized parameters were transferred to the validation period from 1 October 2008 through 30 September 2011. According to the figure, model performance is satisfactory and the result of the validated model confirms the calibration result. However, in both calibration and validation periods the calculated runoff is slightly underestimated. This could be due to the location of rain gauge station within the catchment. Also, recorded data from only one rain gauge station may not represent the whole Baba Arab Basin with a catchment size of $465 \mathrm{~km}^{2}$.

\subsubsection{Effect of climate change on runoff}

As the Baba Arab (adjacent basin to the studied area) catchment size, $465 \mathrm{~km}^{2}$, is about the same as the total size of the two upper catchments of the studied area, Bisheh Zard and Tchah Qootch basins with 192 and $171 \mathrm{~km}^{2}$, respectively, it was assumed that the projected discharge of the Baba Arab Basin is equivalent to the total discharge of the two upper catchments of the studied region. Table 1 shows descriptive statistics of flood events larger than $15 \mathrm{~m}^{3} \mathrm{~s}^{-1}$ day $^{-1}$ for all scenarios and future periods. All scenarios indicate a relative increase in the number of flood events relative to the calibration-validation period with 11 flood events recorded for a 9-year period. Under the B1 scenario, more flood events are projected, particularly, in the near future, which is related to the increase in precipitation for the same period. Although, scenario A2 indicates more precipitation in the far future, more flood events are projected for scenario B1 with less projected precipitation amount. It can be concluded that based upon scenario B1, the area is wetter in both future periods possibly resulting in more flood events. This will lead 
Table 1. Summary statistics of projected runoff for the periods 2010-2030 and 2030-2050.

\begin{tabular}{lccccc}
\hline & $\begin{array}{c}\text { No. of } \\
\text { flood }\end{array}$ & $\begin{array}{c}\text { Min } \\
\left(\mathrm{m}^{3} \mathrm{~s}^{-1} \mathrm{day}{ }^{-1}\right)\end{array}$ & $\begin{array}{c}\text { Mean } \\
\left(\mathrm{m}^{3} \mathrm{~s}^{-1} \mathrm{day}^{-1}\right)\end{array}$ & $\begin{array}{c}\text { Max } \\
\left(\mathrm{m}^{3} \mathrm{~s}^{-1} \mathrm{day}^{-1}\right)\end{array}$ & $\begin{array}{c}\text { SD } \\
\left(\mathrm{m}^{3} \mathrm{~s}^{-1} \mathrm{day}^{-1}\right)\end{array}$ \\
\hline A1B & 24 & 13 & $2010-2030$ & & \\
A2 & 24 & 13 & 47 & 201 & 47 \\
B1 & 28 & 14 & 58 & 189 & 54 \\
\hline & & 63 & 200 & 62 \\
\hline A1B & 19 & 15 & $2030-2050$ & & 53 \\
A2 & 25 & 15 & 65 & 187 & 57 \\
B1 & 26 & 14 & 65 & 193 & 194 \\
\hline
\end{tabular}

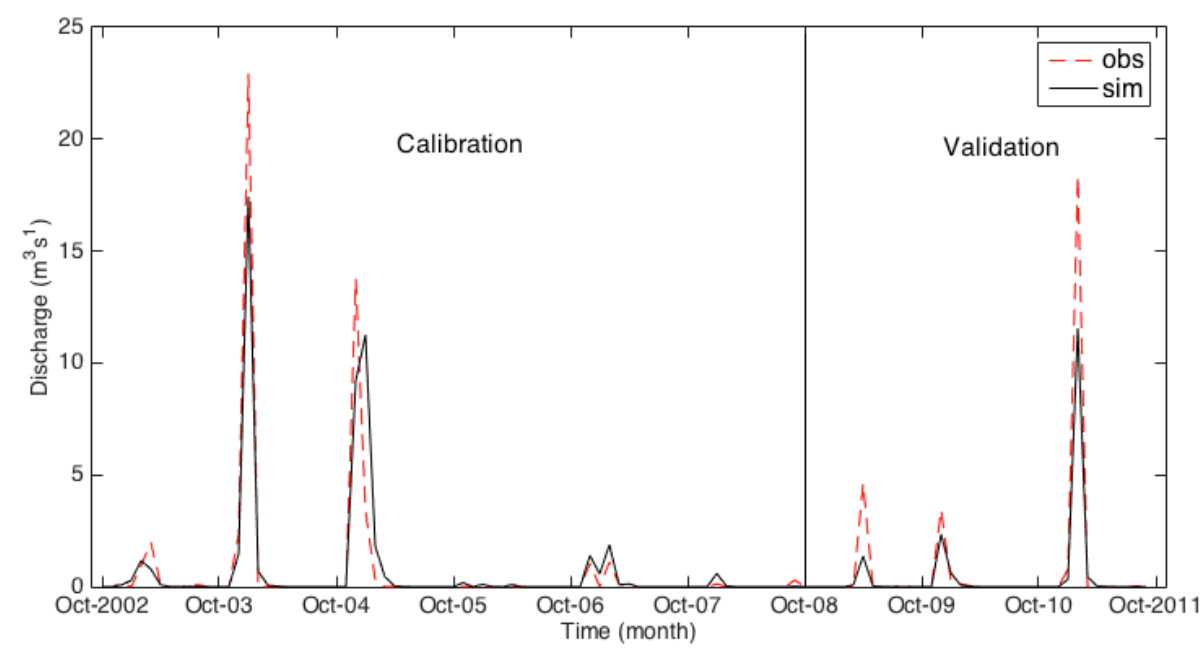

Figure 8. Observed and simulated monthly discharge $\left(\mathrm{m}^{3} \mathrm{~s}^{-1} \mathrm{month}^{-1}\right)$ for the Baba Arab discharge station from 1 October 2002 through 30 September 2011.

to more surface water available that will require proper water management strategies.

\subsection{Effect of climate change on groundwater recharge and adaptation scenarios}

Table 2 shows the amount of projected recharged water for both future scenarios. According to the table, more water is recharged to the aquifer under scenario B1, particularly, in the near future. Under scenario A1B, less water is recharged relative to other scenarios for both near and far future. Further, the far future average recharge $\left(19.3 \mathrm{Mm}^{3}\right)$ is slightly less than for the near future $\left(21 \mathrm{Mm}^{3}\right)$. Therefore, it appears that the studied area will suffer more in terms of decrease in GW availability during 2030-2050.

As mentioned before, four different adaptation scenarios were undertaken to evaluate the impacts of climate change and management on GWL. The average GW drawdown for all emission and adaptation scenarios is presented in Fig. 9. The figure shows a comparison between the historical GWL
Table 2. Projected total recharged water $\left(\right.$ million $\mathrm{m}^{3}$ ) under A1b, $\mathrm{A} 2$, and B1 scenarios for near and far future.

\begin{tabular}{lcccc}
\hline Scenario & $\begin{array}{c}\mathrm{A} 1 \mathrm{~b} \\
\left(\mathrm{Mm}^{3}\right)\end{array}$ & $\begin{array}{c}\mathrm{A} 2 \\
\left(\mathrm{Mm}^{3}\right)\end{array}$ & $\begin{array}{c}\mathrm{B} 1 \\
\left(\mathrm{Mm}^{3}\right)\end{array}$ & $\begin{array}{c}\text { Average } \\
\left(\mathrm{Mm}^{3}\right)\end{array}$ \\
\hline $2010-2030$ & 19.2 & 19.3 & 24.4 & 21.0 \\
$2030-2050$ & 18.1 & 20.6 & 19.3 & 19.3 \\
\hline Total & 37.3 & 39.9 & 43.7 & 40.3 \\
\hline
\end{tabular}

(1993-2013) and the average projected GWL under all emission scenarios (A1B, A2, and B1), taking into account the four adaptation scenarios in the near future. Since the same rate of GW drawdown was seen for both near and far future only results for the near future projection are depicted in Fig. 9.

In the first scenario (Fig. 9a), all conditions were assumed according to the last 20 years of management of water resources in the studied region. For simulation of future con- 

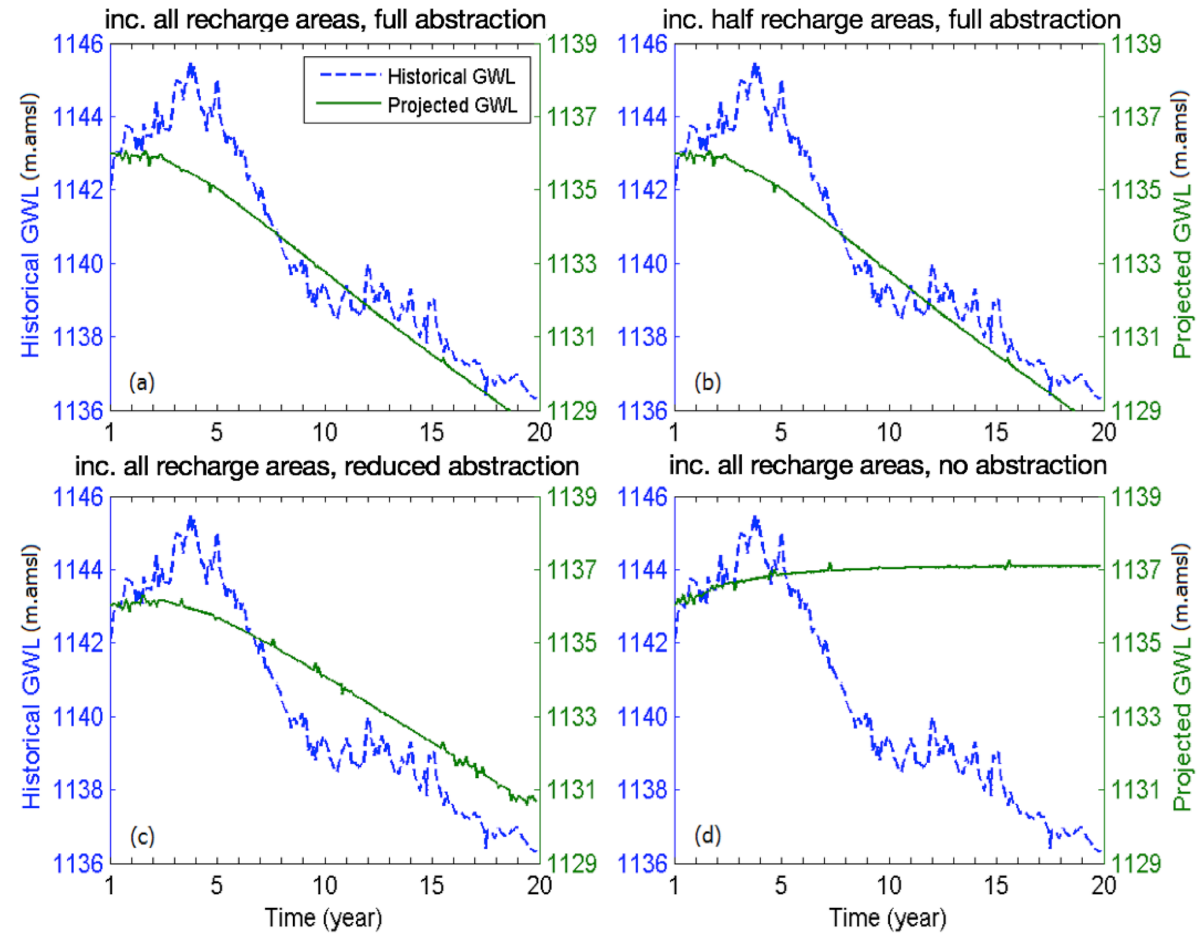

Figure 9. Comparison between historical GWL (1993-2013) and projected GWL (2010-2030) in meter above mean sea level (m a.m.s.1.) taking into account four adaptation scenarios. The left $y$ axis represents the GWL for historical data (dashed line) and the right $y$ axis represents the projected GWL (bold line). (a) shows projected GWL when performing flood spreading in all FWS systems and full abstraction by pumping wells, (b) shows projected GWL when performing flood spreading in half of the FWS systems and full abstraction, (c) shows projected GWL when performing flood spreading in all FWS systems and half abstraction by pumping wells, and (d) shows projected GWL when performing flood spreading in all FWS systems and no abstraction.

ditions, it was assumed that the GWL in the beginning of the simulation was at $1136 \mathrm{~m}$ a.m.s.l. altitude as recorded in 2010. As can be seen, the spatially averaged GWL decreased by about $8 \mathrm{~m}$ below the initial GWL from 2010 to 2030 . The same decline occurred by 2050 (not shown). Consequently, although the recharge takes place through all FWS systems and the river channel, the abstraction has the major effect on the GWL. The GW declines with the same rate as during the last 20 years and the general GWL trend strongly reflects the abstraction associated with water resources management in the area.

In the second scenario (Fig. 9b), the artificial recharge area was decreased by half in order to assess the effect of the FWS system on GW in terms of system size and capacity. Further, the abstraction rate was assumed the same as during the last 20-year pumping rate in the area. It is expected that the GWL will be further affected as the artificial recharge area is decreased by half. However, as seen in the figure the GWL falls with the same rate as in the first management scenario including the entire artificial recharge area. This might be due to the recharge parameters and boundary conditions assigned in the prediction model.

In general, in view of the first and second adaptation scenarios, the GWL may fall beyond the aquifer's bedrock (con- sidering the aquifer saturated thickness) and all productive wells would dry out permanently by 2020 . Furthermore, as the same GW drawdown was assumed for the far future the impact of pumping is doubled by the end of 2050 .

In the third scenario (Fig. 9c), the artificial recharge areas were kept as in the first scenario, but the abstraction was reduced by half of the recorded rate in 2000s. As can be seen, there is still a decline of GWL up to $5 \mathrm{~m}$ that may fall beyond the critical aquifer depth limit in the far future.

In the fourth scenario (Fig. 9d), the artificial recharge areas were kept the same as in the first and third scenarios, but the abstraction rate was reduced to zero (no pumping). Under this scenario, the GWL decline is reversed with no withdrawal for the studied aquifer. However, the GWL increasing rate is still less than the declining rate recorded during the historical period. Applying this scenario up to 2050 would significantly recover the degraded GBP's aquifer and provide an opportunity to manage the GW resources in the far future. 


\section{Discussion}

The methodology for assessing climate change effects in this study can be used to quantify management scenarios on GW resources in arid environments. The developed method is a one-way coupling that can be applied to areas where the GW is rather deep and only the surface water recharges into the GW. In this study, the climate variables were first projected for the near and far future using the delta-change approach under CGCM emission scenarios (A1B, A2, and B1). The output of the climate projection was then transferred to a rainfall-runoff model to project the corresponding runoff for both near and far future. It was assumed, as the GW is semi-deep and the climate of the region is extremely dry, no recharge is taking place from the direct rainfall but instead from the following surface runoff.

In general, the climate variable projection showed slight and not significant increase in rainfall under B1 and A2 scenarios in the near and far future, respectively. However, based on emission scenarios and the delta-change approach, the future climate is likely to replicate the climate pattern of the last 20 years (1990-2010). On the other hand, the studied region has suffered severe droughts during the last decades (1990-2010). Annual precipitation has decreased by $40 \mathrm{~mm}$ in comparison with the average recorded rainfall from 1971 to 1990 (Fig. 7). The projections reveal that reduced rainfall amount is likely to be the predominant condition up to 2050 . Thus, water stress will probably continue to substantially affect the studied region.

It should be mentioned that the ideal case for climate change impact studies on GW resources is to consider the outputs of different GCMs and compare the deltas derived from different models and apply either individually or as an average to the hydrological models. However, in this study the choice of using only one GCM output is related to the scope of this study: (1) to develop a methodology involving a process-based GW model capable of evaluating climate change impacts on GW resources in arid areas, and (2) focusing on system response to different climate change and management scenarios.

The results of the runoff projection showed that the number of flood events may increase under the B1 scenario relative to other scenarios in both the near and far future. This would slightly increase the surface water availability that may lead to more infiltration and percolation to the GW table.

Although, the number of flood events and recharged water in the B1 scenario were larger than other scenarios (Tables 1 and 2), no major differences in GWL was estimated by the GW model between different emission scenarios (A1B, A2, and $\mathrm{B} 1$ ). This is primarily due to the characteristics of the unconfined aquifer and variable amount of $\mathrm{GW}$ inflow from the upper adjacent aquifer and GW outflow to the below adjacent aquifer. Moreover, a similar rate of GW drawdown was predicted by the model for both the near and far future.
In general, assuming the same rate of GW inflow and outflow (unconfined aquifer) and not include any other impacts, i.e., abstraction, on GW reservoir, the mean GWL increased by $2.8,3.0$, and $3.3 \mathrm{~m}$ under $\mathrm{A} 1 \mathrm{~B}, \mathrm{~A} 2$, and $\mathrm{B} 1$ scenarios to 2050 , respectively.

The adaptation and management scenarios were undertaken to find the resilience against GW depletion for the studied aquifer. The results revealed that the GWL may decline by approximately $16 \mathrm{~m}$ by 2050 when using the same rate of abstraction as recorded during the last decades (scenario 1 and 2). As all pumping wells have been deepened to the bedrock and assuming the average aquifer saturated thickness to be 5 to $10 \mathrm{~m}$, the $\mathrm{GW}$ reservoir will be completely depleted by 2030. This will force the farmers who are dependent on GW for irrigation to leave their land and migrate to nearby cities and towns (similar as to the 1960s). This will inevitably cause social and political impacts at both local and national levels. The result also revealed that despite decreasing the rate of abstraction (scenario 3), the GWL still falls with $10 \mathrm{~m}$ by 2050 . This also leads to the absolute depletion of GW reservoirs in the far future.

Under the forth scenario, the simulation revealed that the GW reservoir can be recovered and the GWL decline reversed if the pumping is stopped. Although this would have a major impact on the livelihood of the inhabitants but under the other scenarios (first, second, and third scenarios), pumping causes much damage to the aquifer resulting in no available GW for future farming activity. It is apparent that such over-exploitation and degradation may become permanent as the aquifer may lose its capability of storing water.

The result of the second scenario shows that the change in artificial recharge area may not affect the GWL drawdown. This can, in principal, be due to (1) the recharge parameters assigned in the prediction model and (2) the boundary conditions assigned in the calibration periods. As discussed by Hashemi et al. (2013), the river channel exhibits a high infiltration rate in the case of major flood events relative to the artificial recharge area. Yet, the average value of the river bed's recharge rate was transferred to the prediction model; therefore, the river channel was assumed the main recharge contributor in all future scenarios. This results in no significant impact on GW recharge/level by decreasing the artificial recharge area. To deal with this, more detailed analysis and data are needed to separate the extreme events from normal events.

It can also be mentioned that the boundary conditions assigned for the model are not perfectly representing the actual inflow to and outflow from the aquifer. As discussed by Hashemi et al. (2012), the major source of inflow water to the aquifer is through a fault that transports water from the upper intermountain basin (Bisheh Zard Basin). Thus, not correctly assessed GW inflow through the fault could be a significant error source.

Despite the fact that we believe the GW model is well calibrated based upon available data, we conclude that more de- 
tailed field and geophysical investigations are required to better conceptualize the system in terms of inflow to and outflow from the aquifer. With further investigation, we believe that by numerical modeling we would be able to better predict the future role of artificial recharge in climate change adaptation. Thus, leading to sustainable management of GW resources in the arid area.

In principal, assuming the artificial recharge areas are the main source of GW recharge, extending the FWS systems together by decreasing the abstraction rate seems to be a prominent and affordable solution to reverse the GW decline in the future. This can be accompanied by converting a part of irrigated land into spate irrigation farming (e.g., Ghahari et al., 2014) in order to minimize the pumping rate leading to $\mathrm{GW}$ maintenance. In this case, the impact of reduced pumping would be less on the livelihood of the settlers.

\section{Uncertainty}

Dams et al. (2012) argued that the uncertainty in climate change projections is rather high due to the uncertainties in future greenhouse gas emission prediction. The uncertainty is even larger when the climate change projection scenarios are integrated into hydrological models as the uncertainty accumulates at each step of the coupled approach. Therefore, there are many sources of uncertainty in climate change impact studies (Kay et al., 2009). We address three sources of uncertainty associated with various elements and approaches used in climate change projection and how uncertainty in these sources affects the observed system response.

1. Uncertainty associated with the climate model, which can be assessed by comparing the output of different climate model projections. Thus, the multi-model average projection results are applied for each climate variable in the hydrological models (e.g., Serrat-Capdevila et al., 2007; Stoll et al., 2011; Dams et al., 2012; Barron et al., 2012). In our study we only used a single GCM output. However, our study's contribution to the field of climate change impact studies is to apply a methodology by using a fully process-based GW model for assessing the GW reserve impacted by projected climate change scenarios rather than reducing climate change projection uncertainty. Nevertheless, reducing the climate model uncertainty is a new research area for further study by applying the same methodology.

2. Uncertainty in adaptation of the projected scenarios to the studied area, i.e., the delta-change approach. Studies (e.g., Hay et al., 2000; Kay et al., 2009) have shown that the delta-change approach is likely to underestimate the range of uncertainty simulated from GCMs as it is based on changes to the mean climate. In addition, the delta-change approach does not capture changes on drivers of extreme events and on precipitation distribu- tion within storm events, resulting in uncertainty in the magnitude of surface runoff in the future projections. However, this typical source of uncertainty related to the delta-change approach is not expected to have a large impact on the results as the process-based GW model used, simulates flood recharge based on the assigned flood period and not on the magnitude of the flood. Thus, we acknowledge that the approach gives less information on the range and variation of climate change effects but on the other hand still gives a relevant estimation of change in mean values. Consequently, for our results, the main conclusions regarding climate change on mean GW levels are more certain than the variation around the mean.

3. Hydrologic model structure and parameters uncertainty. Uncertainty and model sensitivity analyses regarding the GW recharge model were documented by Hashemi et al. (2012, 2013). Regarding the rainfallrunoff model, there is a degree of uncertainty mainly associated with input parameters, as they are collected from an adjacent basin, however, with great similarity to the studied basin. Nonetheless, agreement between the simulated and observed discharge values for the river, yielded convincing model calibration and validation results, therefore, less uncertainty (Fig. 8). It should be mentioned that uncertainty in the model results might cause overestimation or underestimation of predicted flood. This would have an impact on the policy of managing water resources and adaptation in the future.

\section{Summary and conclusions}

In arid southern Iran, drought periods during the past couple of decades have already exhausted the GW resources. Projections of climate variables, surface runoff, and GWL were undertaken in order to assess the impacts of climate change on the reservoir in the GBP in arid southern Iran. For this, a sequential modeling approach including results from a GCM, hydrological model, and GW model was employed. The climate variables were projected up to 2050. In the utilized method, the surface runoff was simulated using a calibrated and validated conceptual model. The results of the rainfall-runoff model (flood period) were then imported to the GW recharge model to simulate the GWL response to different adaptation and management scenarios.

Results of projected climate (precipitation, temperature, and ETP) show no significant increase or decrease in rainfall quantity relative to the historical climate but a slight increase in surface runoff. However, minor changes in surface water may result in no change in GWL, which is also confirmed by the GW model. Consequently, on average about $40 \mathrm{Mm}^{3}$ floodwater may recharge the aquifer during the next 40 years. This is insufficient to meet future demand from 
the rural community that is primarily dependent on irrigated agriculture.

According to the GWL prediction, applying the current management of water resources in the studied area, all pumping wells would dry out by the 2020s and this would have severe social and economic impacts on inhabitants. It also appears that the GW abstraction has the most substantial effect on GWL drawdown that needs to be taken into account in the water resources management plan.

Our study showed the capability of one-way coupled surface water and GW recharge models to assess the effects of climate change on a small-scale aquifer $\left(60 \mathrm{~km}^{2}\right)$ by applying climate change projection scenarios to the conceptual hydrological and process-based GW models. In other words, this methodology was developed for linking climate change model output, surface water model, and GW recharge model to investigate the future impacts of climate change on both surface water and dependent GW system through a sequential modeling approach. The $\mathrm{GW}$ recharge model works based upon the GW hydraulic heads and the estimated recharge is directly associated with the reservoirs' behavior. In turn this reflects both climate change impact and current water management in the studied region.

To conclude, the methods used in this study are suitable for assessing the climate change impacts on GW for local-scale aquifer systems. GWL projection by the process-based GW model, particularly in a sophisticated aquifer system, shows great potential of recharge modeling to address the sustainable GW management through adaptation scenarios.

Acknowledgements. The authors wish to thank the Center for Middle Eastern Studies at Lund University for funding this project through the MECW project. The authors are grateful to the Canadian Center for Climate Modeling and Analysis for providing CGCM data. Providing observed daily climate, GWL, and discharge data by Fars Regional Water Authority, Iran are gratefully acknowledged. We would like to extend our gratitude to Lars Bengtsson for supplying the computer code for the rainfallrunoff model.

Edited by: G. Fogg

\section{References}

Abbaspour, K. C., Faramarzi, M., Ghasemi, S. S., and Yang, H.: Assessing the impact of climate change on water resources in Iran, Water. Resour. Res., 45, W10434, doi:10.1029/2008WR007615, 2009.

Ataie-Ashtiani, B., Volker, R., and Lockington, D.: Tidal effects on sea water intrusion in unconfined aquifers, J. Hydrol., 216, 1731, 1999.

Barron, O., Pollock, D., Crosbie, R., Dawes, W., Charles, S., Mpelasoka, F., Aryal, S., Donn, M., and Wurcker, B.: The impact of climate change on groundwater resources: The climate sensitivity of groundwater recharge in Australia, Water for a Healthy
Country Report to National Water Commission, CSIRO, Australia, 2010.

Barron, O., Silberstein, R., Ali, R., Donohue, R., McFarlane, D. J., Davies, P., Hodgson, G., Smart, N., and Donn, M.: Climate change effects on water-dependent ecosystems in south-western Australia, J. Hydrol., 434-435, 95-109, doi:10.1016/j.jhydrol.2012.02.028, 2012.

Barthel, R., Reichenau, T. G., Krimly, T., Dabbert, S., Schneider, K., and Mauser, W.: Integrated modeling of global change impacts on agriculture and groundwater resources, Water. Resour. Manage., 26, 1929-1951, doi:10.1007/s11269-012-0001-9, 2012.

Bedinger, M. S.: Summary of infiltration rates in arid and semiarid regions of the world, with an annotated bibliography, US Geological Survey, Denver, Colorado, 1987.

Bell, J. L., Sloan, L. C., and Snyder, M. A.: Regional changes in extreme climatic events: a future climate scenario, J. Climate, 17, 81-87, 2004.

Beniston, M., Stephenson, D. B., Christensen, O. B., Ferro, C. A., Frei, C., Goyette, S., Halsnaes, K., Holt, T., Jylhä, K., and Koffi, B.: Future extreme events in European climate: an exploration of regional climate model projections, Climatic Change, 81, 71-95, 2007.

Bouwer, H.: Estimating and enhancing groundwater recharge, in: Groundwater Recharge, Balkema Publishers, edited by: Sharma, M. L., Rotterdam, the Netherlands, 1-10, 1989.

Bouwer, H.: Integrated water management: emerging issues and challenges, Agr. Water Manage., 45, 217-228, 2000.

Bou-Zeid, E. and El-Fadel, M.: Climate change and water resources in Lebanon and the Middle East, J. Water Res. Pl.-ASCE, 128, 343-355, doi:10.1061/(ASCE)07339496(2002)128:5(343), 2002.

Brouyère, S., Carabin, G., and Dassargues, A.: Climate change impacts on groundwater resources: modelled deficits in a chalky aquifer, Geer basin, Belgium, Hydrogeol. J., 12, 123-134, doi:10.1007/s10040-003-0293-1, 2004.

Candela, L., von Igel, W., Javier Elorza, F., and Aronica, G.: Impact assessment of combined climate and management scenarios on groundwater resources and associated wetland (Majorca, Spain), J. Hydrol., 376, 510-527, 2009.

Dams, J., Salvadore, E., Van Daele, T., Ntegeka, V., Willems, P., and Batelaan, O.: Spatio-temporal impact of climate change on the groundwater system, Hydrol. Earth Syst. Sci., 16, 1517-1531, doi:10.5194/hess-16-1517-2012, 2012.

Döll, P. and Flörke, M.: Global-Scale estimation of diffuse groundwater recharge: model tuning to local data for semi-arid and arid regions and assessment of climate change impact, Frankfurt Hydrology Paper 03, Institute of Physical Geography, Frankfurt University, Frankfurt am Main, Germany, 2005.

Dore, M. H. I.: Climate change and changes in global precipitation patterns: What do we know?, Environ. Int., 31, 1167-1181, doi:10.1016/j.envint.2005.03.004, 2005.

Dugan, J. T. and Peckenpaugh, J. M.: Effects of climate, vegetation, and soils on consumptive water use and ground-water recharge to the central midwest regional aquifer system, mid-continent United States, Water-resources investigations report 85-4236, US Geological Survey, Lincoln, Nebraska, 1985.

Eckhardt, K. and Ulbrich, U.: Potential impacts of climate change on groundwater recharge and streamflow in a cen- 
tral European low mountain range, J. Hydrol., 284, 244-252, doi:10.1016/j.jhydrol.2003.08.005, 2003.

Evans, J. P.: 21 st century climate change in the Middle East, Climatic Change, 92, 417-432, 2009.

Evans, J. P.: Global warming impact on the dominant precipitation processes in the Middle East, Theor. Appl. Climatol., 99, 389402, 2010.

Felis, T., Lohmann, G., Kuhnert, H., Lorenz, S. J., Scholz, D., Patzold, J., Al-Rousan, S. A., and Al-Moghrabi, S. M.: Increased seasonality in Middle East temperatures during the last interglacial period, Nature, 429, 164-168, 2004.

Ferguson, I. M. and Maxwell, R. M.: Role of groundwater in watershed response and land surface feedbacks under climate change, Water Resour. Res., 46, W00F02, doi:10.1029/2009WR008616, 2010.

Flato, G. M., Boer, G., Lee, W., McFarlane, N., Ramsden, D., Reader, M., and Weaver, A.: The Canadian Centre for Climate Modelling and Analysis global coupled model and its climate, Clim. Dynam., 16, 451-467, 2000.

Ghahari, G. R., Hashemi, H., and Berndtsson, R.: Spate irrigation of barley through floodwater harvesting in the Gareh-Bygone Plain, Iran, Irrig. Drain., 63, 599-611, doi:10.1002/ird.1855, 2014.

Ghayoumian, J., Ghermezcheshme, B., Feiznia, S., and Noroozi, A.: Integrating GIS and DSS for identification of suitable areas for artificial recharge, case study Meimeh Basin, Isfahan, Iran, Environ. Geol., 47, 493-500, doi:10.1007/s00254-004-1169-y, 2005

Giorgi, F. and Lionello, P.: Climate change projections for the Mediterranean region, Global Planet. Change, 63, 90-104, doi:10.1016/j.gloplacha.2007.09.005, 2008.

Goderniaux, P., Brouyère, S., Fowler, H. J., Blenkinsop, S., Therrien, R., Orban, P., and Dassargues, A.: Large scale surfacesubsurface hydrological model to assess climate change impacts on groundwater reserves, J. Hydrol., 373, 122-138, 2009.

Goderniaux, P., Brouyère, S., Blenkinsop, S., Burton, A., Fowler, H. J., Orban, P., and Dassargues, A.: Modeling climate change impacts on groundwater resources using transient stochastic climatic scenarios, Water Resour. Res., 47, W12516, doi:10.1029/2010WR010082, 2011.

Hanson, R. T. and Dettinger, M. D.: Ground water/surface water responses to global climate simulations, Santa Clara-Calleguas Basin, Ventura, California, J. Am. Water Resour. Assoc., 41, 517-536, 2005.

Harbaugh, A. W., Banta, E. R., Hill, M. C., and McDonald, M. G.: MODFLOW-2000, the U.S. Geological Survey modular groundwater model-user guide to modularization concepts and the ground-water flow process, US Geological Survey open-file report 00-92, US Geological Survey, Reston, VA, USA, 2000.

Hashemi, H.: The quantitative evaluation of recharge amount and the effects of floodwater spreading on the groundwater resources of Fasa Gareh-Baygon plain, Fars province, by MODFLOW, MSc Thesis, Department of Natural Resources Engineering, Shiraz University, Shiraz, Iran, 154 pp., 2009.

Hashemi, H., Berndtsson, R., and Kompani-Zare, M.: Steady-state unconfined aquifer simulation of the Gareh-Bygone Plain, Iran, Open Hydrol. J., 6, 58-67, 2012.

Hashemi, H., Berndtsson, R., Kompani-Zare, M., and Persson, M.: Natural vs. artificial groundwater recharge, quantification through inverse modeling, Hydrol. Earth Syst. Sci., 17, 637-650, doi:10.5194/hess-17-637-2013, 2013.

Hashemi, H., Berndtsson, R., and Persson, M.: Artificial recharge by floodwater spreading estimated by water balances and groundwater modelling in arid Iran, Hydrolog. Sci. J., 60, 336350, doi:10.1080/02626667.2014.881485, 2015.

Hay, L. E., Wilby, R. L., and Leavesley, G. H.: A comparison of delta change and downscaled gcm scenarios for three mounfainous basins in the United States, J. Am. Water Resour. Assoc., 36, 387-397, doi:10.1111/j.1752-1688.2000.tb04276.x, 2000.

Henderson-Sellers, A., Yang, Z. L., and Dickinson, R. E.: The project for intercomparison of land-surface parameterization schemes, B. Am. Meteorol. Soc., 74, 1335-1349, 1993.

IPCC-TGICA.: General Guidelines on the Use of Scenario Data for Climate Impact and Adaptation Assessment, Version 2, Prepared by Carter, T. R., on behalf of the Intergovernmental Panel on Climate Change, Task Group on Data and Scenario Support for Impact and Climate Assessment, Finnish Environment Institute, Helsinki, Finland, 66 pp., 2007.

Iritz, L.: Conceptual Modelling of Flood Flow in Central Vietnam. Department of Water Resources Engineering, School of Engineers, Lund University, Sweden, http://www.imh.ac.vn/ btintuc_sukien/dchoinghihoithao/L888-thumucuoi last access: 25 September 2014.

Jyrkama, M. I. and Sykes, J. F.: The impact of climate change on spatially varying groundwater recharge in the grand river watershed (Ontario), J. Hydrol., 338, 237-250, doi:10.1016/j.jhydrol.2007.02.036, 2007.

Kay, A. L., Davies, H. N, Bell, V. A., and Jones, R. G.: Comparison of uncertainty sources for climate change impacts: flood frequency in England, Climatic Change, 92, 41-63, 2009.

Kløve, B., Ala-Aho, P., Bertrand, G., Gurdak, J. J., Kupfersberger, H., Kværner, J., Muotka, T., Mykrä, H., Preda, E., and Rossi, P.: Climate change impacts on groundwater and dependent ecosystems, J. Hydrol., 518, 250-266, doi:10.1016/j.jhydrol.2013.06.037, 2014.

Kowsar, S. A.: Floodwater spreading for desertification control: an integrated approach, Desert. Control Bull., 19, 3-18, 1991.

Kowsar, S. A.: Desertification control through floodwater harvesting: the current state of know-how. The Future of Drylands, Springer, the Netherlands, 229-241, 2008.

Leterme, B., Mallants, D., and Jacques, D.: Sensitivity of groundwater recharge using climatic analogues and HYDRUS-1D, Hydrol. Earth Syst. Sci., 16, 2485-2497, doi:10.5194/hess-16-24852012, 2012.

Lindström, G., Johansson, B., Persson, M., Gardelin, M., and Bergström, S.: Development and test of the distributed HBV-96 hydrological model, J. Hydrol., 201, 272-288, doi:10.1016/S0022-1694(97)00041-3, 1997.

Llamas, M. R. and Martínez-Santos, P.: Intensive groundwater use: silent revolution and potential source of social conflicts, J. Water Resour. Pl.-ASCE, 131, 337-341, 2005.

McMichael, A. J., Campbell-Lendrum, D., Kovats, S., Edwards, S., Wilkinson, P., Wilson, T., Nicholls, R., Hales, S., Tanser, F., Le Sueur, D., Schlesinger, M., and Andronova, N.: Chapter 20: Global Climate change, in: Comparative quantification of health risks: global and regional burden of disease due to selected major risk factors, edited by: Ezzati, M., Lopez, A., Rodgers, A., 
and Murray, C., World Health Organization, Geneva, 1543-1649, 2004.

Meddi, M. and Boucefiane, A.: Climate change impact on groundwater in Cheliff-Zahrez Basin (Algeria), APCBEE Procedia, 5, 446-450, 2013.

Ng, G.-H. C., McLaughlin, D., Entekhabi, D., and Scanlon, B. R.: Probabilistic analysis of the effects of climate change on groundwater recharge, Water Resour. Res., 46, W07502, doi:10.1029/2009WR007904, 2010.

Okkonen, J. and Kløve, B.: A sequential modelling approach to assess groundwater-surface water resources in a snow dominated region of Finland, J. Hydrol., 411, 91-107, doi:10.1016/j.jhydrol.2011.09.038, 2011.

Priyantha Ranjan, S., Kazama, S., and Sawamoto, M.: Effects of climate and land use changes on groundwater resources in coastal aquifers, J. Environ. Manage., 80, 25-35, doi:10.1016/j.jenvman.2005.08.008, 2006.

Robock, A., Vinnikov, K. Y., Schlosser, C. A., Speranskaya, N. A., and Xue, Y.: Use of midlatitude soil moisture and meteorological observations to validate soil moisture simulations with biosphere and bucket models, J. Climate, 8, 15-35, 1995.

Rosegrant, M. W. and Ringler, C.: Impact on food security and rural development of transferring water out of agriculture, Water Policy, 1, 567-586, doi:10.1016/S1366-7017(99)00018-5, 2000.

Scibek, J. and Allen, D.: Modeled impacts of predicted climate change on recharge and groundwater levels, Water Resour. Res., 42, W11405, doi:10.1029/2005WR004742, 2006.

Şen, Z.: Wadi hydrology, 1st Edn., CRC Press, Taylor \& Francis Group, Broken Sound Parkway NW, USA, 347 pp., 2008.

Seneviratne, S. I., Corti, T., Davin, E. L., Hirschi, M., Jaeger, E. B., Lehner, I., Orlowsky, B., and Teuling, A. J.: Investigating soil moisture-climate interactions in a changing climate: A review, Earth-Sci. Rev., 99, 125-161, 2010.

Serrat-Capdevila, A., Valdés, J. B., Pérez, J. G., Baird, K., Mata, L. J., and Maddock, T.: Modeling climate change impacts - and uncertainty - on the hydrology of a riparian system: The San Pedro Basin (Arizona/Sonora), J. Hydrol., 347, 48-66, 2007.
Siebert, S., Burke, J., Faures, J. M., Frenken, K., Hoogeveen, J., Döll, P., and Portmann, F. T.: Groundwater use for irrigation - a global inventory, Hydrol. Earth Syst. Sci., 14, 1863-1880, doi:10.5194/hess-14-1863-2010, 2010.

Stoll, S., Franssen, H., Butts, M., and Kinzelbach, W.: Analysis of the impact of climate change on groundwater related hydrological fluxes: a multi-model approach including different downscaling methods, Hydrol. Earth Syst. Sci., 15, 21-38, doi:10.5194/hess-15-21-2011, 2011.

Sulis, M., Paniconi, C., Rivard, C., Harvey, R., and Chaumont, D.: Assessment of climate change impacts at the catchment scale with a detailed hydrological model of surface-subsurface interactions and comparison with a land surface model, Water Resour. Res., 47, W01513, doi:10.1029/2010WR009167, 2011.

Surinaidu, L., Bacon, C. G. D., and Pavelic, P.: Agricultural groundwater management in the Upper Bhima Basin, India: current status and future scenarios, Hydrol. Earth Syst. Sci., 17, 507-517, doi:10.5194/hess-17-507-2013, 2013.

Toews, M. and Allen, D.: Simulated response of groundwater to predicted recharge in a semi-arid region using a scenario of modelled climate change, Environ. Res. Lett., 4, 035003 , doi:10.1088/1748-9326/4/3/035003, 2009.

van Roosmalen, L., Sonnenborg, T. O., and Jensen, K. H.: Impact of climate and land use change on the hydrology of a largescale agricultural catchment, Water Resour. Res., 45, W00A15, doi:10.1029/2007WR006760, 2009.

Zhang, Y., Xu, Y., Dong, W., Cao, L., and Sparrow, M.: A future climate scenario of regional changes in extreme climate events over China using the PRECIS climate model, Geophys. Res. Lett., 33, L24702, doi:10.1029/2006GL027229, 2006. 